\begin{abstract}
Iranica
Abstracta Iranica Revue bibliographique pour le domaine irano-aryen

Volume 34-35-36 | 2017

Comptes rendus des publications de 2011-2013
\end{abstract}

\title{
Edward DĄbrowa. Greek: a Language of the Parthian Empire
}

\section{Fabrizio Sinisi}

\section{(2) OpenEdition \\ Journals}

Electronic version

URL: http://journals.openedition.org/abstractairanica/42347

DOI: $10.4000 /$ abstractairanica. 42347

ISSN: 1961-960X

\section{Publisher:}

CNRS (UMR 7528 Mondes iraniens et indiens), Éditions de l'IFRI

\section{Electronic reference}

Fabrizio Sinisi, «Edward Dąbrowa. Greek: a Language of the Parthian Empire », Abstracta Iranica [Online], Volume 34-35-36 | 2017, document 58, Online since 30 July 2017, connection on 26 September 2020. URL : http://journals.openedition.org/abstractairanica/42347 ; DOI : https://doi.org/10.4000/ abstractairanica.42347

This text was automatically generated on 26 September 2020.

Tous droits réservés 


\title{
Edward DĄbrowa. Greek: a Language of the Parthian Empire
}

\author{
Fabrizio Sinisi
}

\section{REFERENCES}

Edward DĄbrowa. " Greek: a Language of the Parthian Empire », in: E. DĄbrowa, ed., Studia Graeco-Parthica. Political and Cultural Relations between Greeks and Parthians.

Wiesbaden, 2011, p. 153-163. (Philippika, 49)

1 The special status enjoyed by Greek language in the Parthian empire was due to the role of the Greeks and the weight of the Seleucid heritage in the building by the Arsacids of an ideological community to support their new state. Indeed, the legends of coins struck all across the empire show that the Arsacids used Greek to communicate not only with Greeks. The quality of the legends and of the engraving on coins started to decline from the early 1st century BC, and we can accordingly determine when the Arsacids no longer needed to be primarily concerned about their Greek subjects. With the increasing reliance on a neo-Iranian policy by the dynasty, the use of Greek was gradually limited to communication with large centers of Greek population in the most hellenized areas. However, Greek remained in use as official language until the end of the dynasty. 


\section{AUTHORS}

FABRIZIO SINISI

Österreichische Akademie der Wissenschaften 